\title{
A Survey of the Common Mutations and IVS8-Tn Polymorphism of Cystic Fibrosis Transmembrane Conductance Regulator Gene in Infertile Men with Nonobstructive Azoospermia and CBAVD in Iranian Population
}

\author{
Fatemeh Asadi ${ }^{1,2 *}$, Reza Mirfakhraie ${ }^{3}$, Farzaneh Mirzajani ${ }^{4,5}$ and Azam Khedri ${ }^{6}$ \\ ${ }^{1}$ Department of Molecular Genetics, Marvdasht Branch, Islamic Azad University, Marvdasht, Iran; ${ }^{2}$ Department of \\ Molecular Genetics, Science and Research Branch, Islamic Azad University, Fars, Iran; ${ }^{3}$ Department of Medical Genetics, \\ Shahid Beheshti University of Medical Sciences, Tehran, Iran; ${ }^{4}$ St. Justine Hospital, Montreal University, Montreal, \\ Canada; ${ }^{5}$ Medical Genetics Department of the National Institute of Genetic Engineering and Biotechnology, Tehran, \\ Iran; ${ }^{6}$ Department of Biochemistry, Faculty of Medicine, Tehran University of Medical Science, Tehran, Iran
}

Received 20 October 2017; revised 18 April 2018; accepted 27 May 2018

\begin{abstract}
Background: Studies have revealed a strong association between mutations of CFTR gene and the congenital bilateral absence of the vas deferens (CBAVD), but the role of this gene in other types of male infertility is still unclear. The purpose of this study was to investigate the frequency of the most common mutations of the CFTR gene $(\triangle F 508, G 542 X, N 1303 K, G 551 D$, and $W 1282 X)$ in a population of infertile men with nonobstructive azoospermia (NOA) and CBAVD in Iran. Methods: Blood samples were obtained from 50 NOA, 50 CBAVD, and 100 normal males (control). Genomic DNA was isolated from whole blood leukocytes, and the presence of common mutations of the CFTR gene was assessed by an amplification refractory mutation system-polymerase chain reaction (ARMS-PCR). Restriction fragment length polymorphism (PCR-RFLP) was also used to analyze IVS8-Tn polymorphism. Results: It was found that $16 \%, 8 \%$, and $8 \%$ of patients with CBAVD were heterozygote for $\triangle \mathrm{F} 508$, G542X, and N1303K, respectively. The frequency of the $5 \mathrm{~T}$ allele was $34 \%$ and higher than the normal group $(p<$ 0.001). None of the common CFTR gene mutations were detected in NOA patients, and no significant difference was found in the distribution of the 5T allele between the NOA patients and the control group (5 vs. $3 p=0.721$ ). Conclusion: Based on the present case-control study, the CFTR gene mutations and IVS8-Tn polymorphisms are correlated with CBAVD; however, extensive investigations are necessary to determine the exact relationship between the gene mutations and other forms of male infertility. DOI: 10.29252/ibj.23.2.92
\end{abstract}

Keywords: Azoospermia, CFTR, Congenital bilateral absence of the vas deferens, Male Infertility, Mutation

Corresponding Author: Fatemeh Asadi

Department of Molecular Genetics, Marvdasht Branch, Islamic Azad University, Marvdasht, Iran; Tel.: (+98-71) 43311172; Fax: (+98-71) 43112201;

E-mail: Fatemehasadi@miau.ac.ir

\section{INTRODUCTION}

I nfertility is commonly known as the inability to become pregnant after one year of frequent intercourse, in the absence of a contraceptive ${ }^{[1]}$. Male infertility is a major health problem in the global populations; its prevalence in Western countries has been estimated to be about $20 \%{ }^{[2]}$. The main causes of male factor infertility are azoospermia, asthenozoospermia, teratozoospermia, and oligozoospermia. Azoospermia is characterized as the lack of sperms in the ejaculate, and it can be divided into two groups: nonobstructive azoospermia (NOA) and obstructive azoospermia (OA). The former is usually due to spermatogenesis failure, while the latter is caused by an obstruction in the seminal tract (epididymis, vas deferens, and ejaculatory ducts) ${ }^{[3-5]}$. The congenital bilateral absence of the vas deferens 
(CBAVD) accounted for 25\% of cases of OA and 1.5\% of male infertility ${ }^{[6,7]}$.

It has been estimated that more than 3000 genes are involved in the genetic regulation of male or female fertility ${ }^{[8-10]}$. The CFTR gene is located on chromosome 7 (7q31.2) and contains 27 exons that span $190 \mathrm{~kb}$ of genomic DNA. It encodes a chloride channel in epithelial cells. Mutations in this gene result in cystic fibrosis (CF). The clinical manifestations of $\mathrm{CF}$ include chronic obstructive pulmonary disease, pancreatic insufficiency, high levels of sweat electrolytes, and male infertility ${ }^{[11,12]}$. In most cases, CBAVD is regarded as a genital form of $\mathrm{CF}$, without other clinical manifestations ${ }^{[13]}$. More than 2000 mutations of the CFTR gene have been found, which has led to a variety of clinical phenotypes of $\mathrm{CF}^{[14]} . \Delta \mathrm{F} 508, \mathrm{~N} 1303 \mathrm{~K}$, and G542X have been identified as the most frequent CF-causing mutations worldwide. Several studies have reported the role of CFTR gene mutations in CBAVD in men and congenital unilateral absence of the vas deferens ${ }^{[1,15-17]}$. The CFTR gene mutations associated with this disorder are as follows: $\triangle \mathrm{F} 508, \mathrm{R} 117 \mathrm{H}$, G551D, D1152H, G542X, M470W, R334W, R74W, M9521, W1282X, N1303K, and G85E ${ }^{[18-20]}$. Based on the phenotypic effects, there are usually two types of alleles in the CF genotype: (1) severe allele and (2) mild allele. $\triangle \mathrm{F} 508$ and $\mathrm{G} 542 \mathrm{X}$ are characterized as severe alleles, while $\mathrm{R} 117 \mathrm{H}$ is regarded as a mild allele. Numerous reports have indicated that CFTR gene can be involved in another cases of infertility other than CBAVD ${ }^{[21-23]}$. However, it is not known for sure whether these mutations have an important function in the spermatogenesis and NOA.

The present study aimed to evaluate the frequency of common mutations of the CFTR gene including, $\triangle \mathrm{F} 508, \mathrm{G} 551 \mathrm{D}, \mathrm{G} 542 \mathrm{X}, \mathrm{N} 1303 \mathrm{~K}$, and $\mathrm{W} 1282 \mathrm{X}$ in Iranian infertile men with NOA and CBAVD using ARMS-PCR technique. Also, IVS8-Tn polymorphism was analyzed by RFLP-PCR.

\section{MATERIALS AND METHODS}

This case-control study was conducted on 50 CBAVD patients, 50 NOA patients, and a control group $(\mathrm{n}=100)$, who had at least one child; the patients came from Yazd Infertility Center (Yazd) and Mirza Koochak Khan Hospital (Tehran, Iran). The study was conducted at the Medical Genetics Department of the National Institute of Genetic Engineering and Biotechnology (NIGEB, Tehran). The diagnosis of CBAVD was initially suggested by palpable scrotal vas deferens on physical examination and transabdominal/rectal ultrasonography and then confirmed by cytobiochemical characteristics, according to the World Health Organization criteria $^{[24,25]}$. The diagnosis of NOA was based on the following examinations: normal semen volume, normal testicular size, presence of the vas deferens by clinical examination, and normal levels of serum folliclestimulating hormone and also according to the medical history of patients; none of them had chromosomal aberrations or Y-chromosome microdeletions. No other symptoms of $\mathrm{CF}$ such as chronic lung inflammation/ infection, pancreatic insufficiency, and intestinal obstruction were observed in these patients. All subjects gave their written informed consent, and then $5 \mathrm{~mL}$ of whole blood sample was collected in EDTA vacuum tubes (Becton Dickinson, USA). Genomic DNA was extracted from peripheral blood leukocyte by salting-out method and was analyzed for the most common CF mutations, including $\triangle \mathrm{F} 508$, G551D, G542X, N1303K, and W1282X using amplification refractory mutation system-polymerase chain reaction (ARMS-PCR) method as described previously ${ }^{[26]}$. IVS8-Tn polymorphism was analyzed by using restriction fragment length polymorphism (RFLP)PCR. The CF intron 8/exon 9 (product size: 259-261 bp) primers were as follows: common downstream primer, CF9RR: GACATGGACACCA AATTAAG; upstream primer, CF5T: TGTGTGTGTGTGTGTGTT G*TT), and upstream primer, CF7T: GTGTGT GTGTGTGTGTTTTG*TT; *denotes a mismatch. Amplification reaction was performed using a conventional protocol: the reaction mixture contained $10 \mathrm{mM}$ of Tris- $\mathrm{HCl}(\mathrm{pH} 8.3), 50 \mathrm{mM}$ of $\mathrm{KCl}, 1.5 \mathrm{mM}$ of $\mathrm{MgCl}_{2}, 0.01 \mathrm{mg} / \mathrm{mL}$ of gelatin, $0.2 \mathrm{mM}$ of each deoxynucleotide, and $0.75 \mathrm{mM}$ of each primer and $1 \mathrm{U}$ of AmpliTaq Polymerase in a total volume of $25 \mu \mathrm{l}$. The PCR thermal cycles were: $94{ }^{\circ} \mathrm{C}$ for $5 \mathrm{~min}$, followed by 32 cycles of $1 \mathrm{~min}$ at $94{ }^{\circ} \mathrm{C}, 1 \mathrm{~min}$ at $58{ }^{\circ} \mathrm{C}$ (annealing), $1 \mathrm{~min}$ at $72{ }^{\circ} \mathrm{C}$ (extension), and a final extension of $5 \mathrm{~min}$ at $72{ }^{\circ} \mathrm{C}$. Twenty microliters of the amplified product of 260 to $264 \mathrm{bp}$ (intron 8) was digested with 5 to $10 \mathrm{U} \mathrm{HpaI}$ for $3 \mathrm{~h}$ or at $37{ }^{\circ} \mathrm{C}$ overnight. After digestion with $\mathrm{HpaI}$, the products were run on an $8 \%$ acrylamide gel with $0.5 \times$ Trisborate-ethylenediaminetetraacetic acid at $200 \mathrm{~V}$ for $3 \mathrm{~h}$ (Fig. 1). The expected product sizes of different digests are listed in Table $1^{[27]}$. The differences between both groups (patients and control) were analyzed using SPSS for Windows software (version 18.0). All $p$ values were based on two-sided comparisons. $p$ values less than 0.05 were considered to indicate statistical significance. 


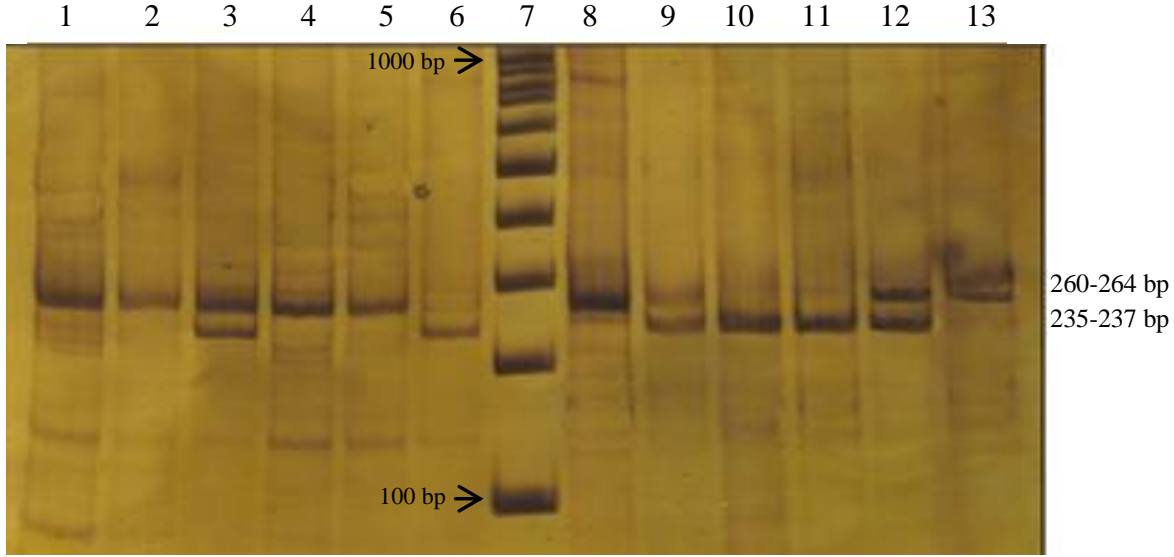

Fig. 1. Ag- $\mathrm{NO}_{3}$-stained polyacrylamide gel for the evaluation of IVS8-Tn polymorphism. Lanes 1 and 8, uncut PCR products; lanes 2-6, digestion results of CF5T/CF9RR products; Lane 7, $100 \mathrm{pb}$ DNA ladder; lanes 9-13, digestion results of CF7T/CF9RR products. Lanes 2 and 9, 7T/9T; lanes 3 and 10, 5T/7T; lanes 4 and 11, 7T/7T; lanes 5 and 12, 7T/9T; lanes 6 and 13, 5T/5T.

Table 1. Intron 8 variation detectable by $H p a$ I restriction digest

\begin{tabular}{ccc}
\hline Result of digested & \multicolumn{2}{c}{ Primers } \\
\cline { 2 - 3 } products & CF5T/CF9RR & CF7T/CF9RR \\
\hline Restriction enzyme & HpaI & HpaI \\
IVS8-5T allele & $237+22(+)$ & $235+22(+)$ \\
IVS8-7T allele & $261(-)$ & $237+22(+)$ \\
IVS8-9T allele & $263(-)$ & $261(-)$ \\
IVS8 genotype & & \\
$5 T / 5 T$ & $+/+$ & $-/-$ \\
$5 T / 7 T$ & $+/-$ & $+/+$ \\
$5 T / 9 T$ & $+/-$ & $-/-$ \\
$7 T / 7 T$ & $-/-$ & $+/+$ \\
$7 T / 9 T$ & $-/-$ & $+/-$ \\
$9 T / 9 T$ & $-/-$ & $-/-$ \\
\hline
\end{tabular}

Each genotype has a unique $\mathrm{HpaI}$ digest pattern when both PCR products are considered.

\section{RESULTS}

Mutation analysis was performed on all the 100 patients (NOA and CBAVD patients) and 100 fertile controls. Among the CBAVD patients, 8/50 (16\%), $4 / 50(8 \%)$, and $4 / 50 \quad(8 \%)$ of subjects were heterozygote for $\Delta \mathrm{F} 508, \mathrm{G} 542 \mathrm{X}$, and $\mathrm{N} 1303 \mathrm{~K}$, respectively, accounting for $16 \%$ of all mutant alleles (Table 2 and Fig. 2).

In the screening of IVS8-Tn polymorphism, seven of the 50 CBAVD patients had the 5T/5T genotype, nine were heterozygous for the 5T/9T genotype, and 11 were heterozygous for the 5T/7T genotype. The frequency of $5 \mathrm{~T}$ alleles was $34 \%$. The number of patients with genotypes of 9T/9T, 9T/7T, and 7T/7T were 4,7 , and 12 , respectively (Table 3 ). None of the CFTR gene mutations were detected in NOA patients, and the frequency of the $5 \mathrm{~T}$ allele $(5 \%)$ was similar to the control group. The final results of the IVS8-Tn genotype in NOA and CBVDpatients are presented in Table 3. The frequency of 5T, 7T, and 9T alleles in both groups of the patients and the control are shown in Table 4.

\section{DISCUSSION}

About $97 \%$ of men with CF are infertile as a result of CBAVD and OA. In addition, defects in the CFTR gene may affect the process of spermatogenesis ${ }^{[19,20,23]}$. The frequency of mutations within the CFTR gene varies in different populations. $\triangle \mathrm{F} 508$ is known as the most prevalent mutation in the world ${ }^{[28]}$. It has also been reported as the most common allele in Iranian $\mathrm{CF}$ patients. The other most common mutations are W1282X, G542X, R347H, and $\mathrm{R} 117 \mathrm{H}^{[29,30]}$. Although numerous investigations have revealed the relationship of CFTR gene with infertility problem in populations all over the world, a limited number of such studies have been published in males with CBAVD and other types of infertility in Iran. Hence, the objective of the present study was to investigate the most prevalent mutations in CFTR gene in Iranian

Table 2. Frequency of mutations in CBAVD patients

\begin{tabular}{cccc}
\hline Mutation & Genotype & $\begin{array}{c}\text { CBAVD } \\
\text { patients } \\
(\mathbf{n = 1 6})\end{array}$ & $\begin{array}{c}\text { Genotypic } \\
\text { frequencies } \\
(\mathbf{n = 3 2})\end{array}$ \\
\hline G542X & G542X/- & 4 & 8 \\
N1303K & N1303K/- & 4 & 8 \\
$\Delta$ F508 & $\Delta$ F508/- & 8 & 16 \\
W1282X & $-/-$ & & \\
G551D & $-/-$ & & \\
\hline
\end{tabular}


Table 3. Final results of IVS8-Tn polymorphism in nonobstructive azoospermia (NOA) and congenital bilateral absence of the vas deferens (CBAVD) patients

\begin{tabular}{ccccc}
\hline CF5T/CF9RR & CF7T/CF9RR & IVS8-Tn & $\begin{array}{c}\text { NOA patients } \\
(\mathbf{n}=50)\end{array}$ & $\begin{array}{c}\text { CBAVD patients } \\
(\mathbf{n}=50)\end{array}$ \\
\hline$-/-$ & $+/-$ & $9 \mathrm{~T} / 7 \mathrm{~T}$ & 17 & 7 \\
$-/-$ & $+/+$ & $7 \mathrm{~T} / 7 \mathrm{~T}$ & 9 & 12 \\
$+/-$ & $-/-$ & $5 \mathrm{~T} / 9 \mathrm{~T}$ & 2 & 4 \\
$-/-$ & $-/-$ & $9 \mathrm{~T} / 9 \mathrm{~T}$ & 20 & 7 \\
$+/+$ & $-/-$ & $5 \mathrm{~T} / 5 \mathrm{~T}$ & 1 & 11 \\
$-/+$ & $+/+$ & $5 \mathrm{~T} / 7 \mathrm{~T}$ & 1 & \\
\hline
\end{tabular}

infertile men (CBAVD and NOA). Selection of the most common mutations ( $\triangle \mathrm{F} 508$, G551D, G542X, $\mathrm{N} 1303 \mathrm{~K}$, and $\mathrm{W} 1282 \mathrm{X}$ ) was based on the high prevalence of these mutations reported in the CFTR gene worldwide and also based on the presence of these mutations in patients with CBAVD ${ }^{[19,20]}$.

In our CBAVD patients, $\triangle \mathrm{F} 508$ with a frequency of $8 \%$ was detected as the most common mutation, and then N1303K and G542X (4\% and 4\%, respectively) were found, which it was significantly greater than that of the control group $(p<0.001)$. The 5T allele showed a significantly higher rate compared to the control group (34\% ver. $3 \%, p<0.001)$. These results are consistent with several investigations that evaluated CFTR mutations in CBAVD, as well as mutations of $\Delta \mathrm{F} 508, \quad 5 \mathrm{~T}$, and $\mathrm{R} 117 \mathrm{H}$ as the prevalent variations $^{[6,16,31]}$.

In 2007, Radpour et al. ${ }^{[32]}$ published a paper in which different types of mutations were found in the CFTR gene among Iranian CBAVD patients. $\triangle$ F508 had a high prevalence in patients, and the frequency of IVS85T was $27.23 \%$, which corresponds to the present investigation (34\%). Approximately $35 \%$ of Iranian men with CBAVD are carriers for a single mutation or polymorphism in CFTR gene, and around $40 \%$ have two mutations (common CFTR mutations or IVS8-5T polymorphism $)^{[32,33]}$. The frequency of IVS8-5T in our patients was similar to that of Portuguese $(27.4 \%)^{[34]}$ and Taiwanese patients $(29.2 \%)^{[35]}$ but higher than Turkish $(19.6 \%)^{[31]}$.

In our study, the proportion of patients with NOA who had the $5 \mathrm{~T}$ allele was the same as normal population ( 5 vs. $3 ; p=0.721$ ). No mutation was found in this group of patients and healthy normal samples. The findings of the present study have some similarities and differences to some previous studies. In the study performed by Heidari et al. ${ }^{[32]}$ for screening two CFTR mutations $(\triangle \mathrm{I} 507$ and $\triangle \mathrm{F} 508)$ in Iranian men with NOA, the $\Delta \mathrm{F} 508$ was found in three individuals; no statistically significant relationship was found between this mutation and $\mathrm{NOA}^{[36]}$. In a recent study, Jiang et al. ${ }^{[37]}$ investigated the prevalence of $\Delta \mathrm{F} 508$ and $\mathrm{R} 117 \mathrm{H}$ mutations, IVS8 poly(T) and TG repeats, in Chinese NOA patients. Their result indicated no mutation in patients and fertile controls, suggesting that these two mutations have a low possibility of being associated with NOA condition. Besides, the T5 allele was identified as the most prevalent factor that increases the risk of having NOA in Chinese.

In the evaluation of $C F T R$ gene mutations in males with various types of abnormal sperm parameters by Ślęzak et al. ${ }^{[38]}$ who observed that $\Delta \mathrm{F} 508$ and IVS8-T occurred in $5.4 \%$ of patients, which was similar to the general population. van der Ven et al. ${ }^{[21]}$ have screened 127 males with poor sperm quality for 13 CFTR gene mutations. The frequency of mutations was significantly higher than the expected CF carrier frequency in the general population, and no mutations were detected in the control group, which was different from our work. In 2011, Safinejad et al. ${ }^{[39]}$ evaluated the common $C F T R$ mutations $(\triangle \mathrm{F} 508, \mathrm{G} 542 \mathrm{X}, \mathrm{R} 117 \mathrm{H}$, $\mathrm{W} 1282 \mathrm{X}$, and $\mathrm{N} 1303 \mathrm{~K}$ ) and the frequency of the $5 \mathrm{~T}$ variant in men with non-CAVD OA. Their result revealed that $5 / 53(9.43 \%)$ and $4 / 53(7.55 \%)$ of patients were heterozygote for $\Delta \mathrm{F} 508$ and G542X mutations, respectively, and $5 \mathrm{~T}$ polymorphism was $14 \%$, which was more frequent than the control subjects $(3 \% ; p<$ 0.05). In another research that was carried out on 1195 males with nonobstructive infertility and those with

Table 4. Frequency of IVS8-Tn and mutations of CFTR gene identified in Iranian NOA and CBAVD patients

\begin{tabular}{lcccccccc}
\hline Alleles & $\mathbf{5 T}$ & $\mathbf{7 T}$ & $\mathbf{9 T}$ & $\mathbf{G 5 4 2 X}$ & $\mathbf{N 1 3 0 3 K}$ & $\mathbf{\Delta F 5 0 8}$ & $\mathbf{G 5 5 1 D}$ & W1282X \\
\hline NOA $(\mathrm{n}=50)$ & $5 / 100$ & $36 / 100$ & $59 / 100$ & & & & & \\
CBAVD $(\mathrm{n}=50)$ & $34 / 100$ & $42 / 100$ & $24 / 100$ & $4 / 100$ & $4 / 100$ & $8 / 100$ & $0 / 100$ & $0 / 100$ \\
Control $(\mathrm{n}=100)$ & $3 / 100$ & $39 / 100$ & $58 / 100$ & & & & & \\
\hline
\end{tabular}




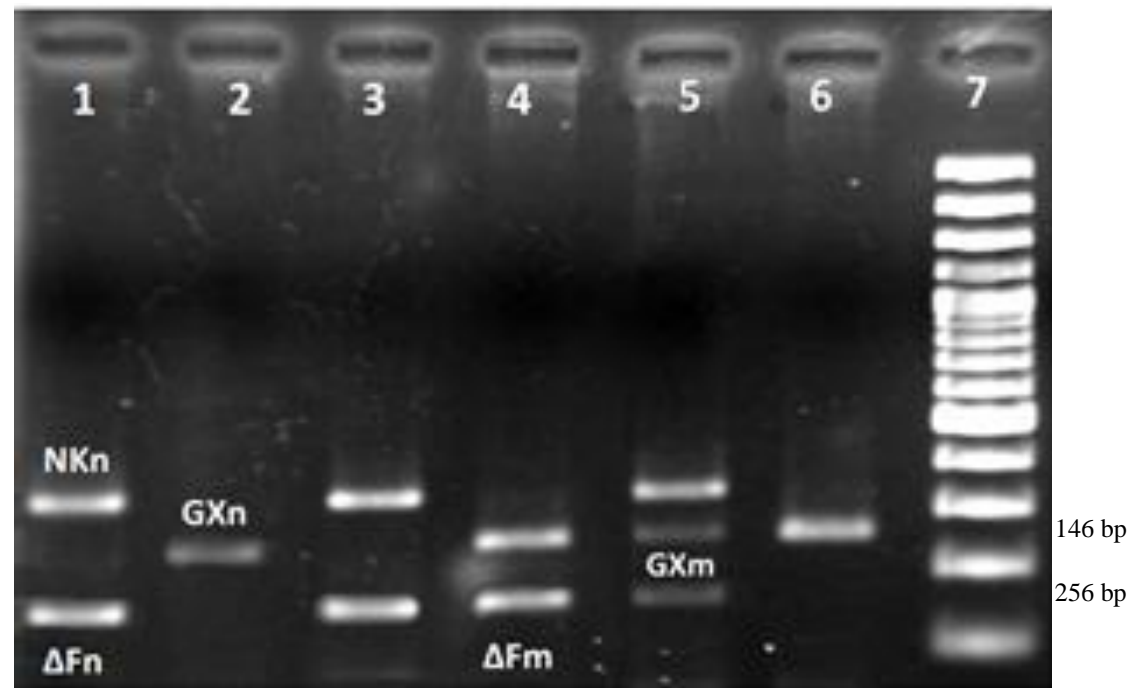

Fig. 2. Detection of the most common $C F T R$ mutations in CBAVD men by using multiplex ARMS-PCR. Lanes 1 and 2, fertile group (control); lane 3 and 4 , heterozygote patients for $\Delta \mathrm{F} 508$ mutation $(\Delta \mathrm{Fm})$; Lanes 5 and 6 , heterozygote patient for G542X mutation $(\mathrm{GXm})$; Lane 7, $100 \mathrm{pb}$ DNA ladder. NKn, $\Delta \mathrm{Fn}$, and GXn represent the PCR products for normal alleles N1303K, $\Delta \mathrm{F} 508$ and G542X, respectively.

unexplained infertility, no significant difference in CFTR gene was identified between the control group and patients ${ }^{[40]}$. Sharma et al. ${ }^{[4]]}$ have examined the frequency of CFTR mutations in Indian infertile patients with NOA and spermatogenic failure. They reported $\Delta \mathrm{F} 508$ mutation in $3.6 \%$ of men with NOA. In this study, a significant correlation was detected between the most common mutations of the CFTR gene and IVS8-Tn polymorphism in CBAVD patients. However, the relationship between this gene and NOA remains under question. Thus, large-scale cohort studies as well as examination of entire gene or the high number of CFTR mutations may be necessary to substantiate the hypothesis of a putative link between a particular combination of CFTR mutations and polymorphisms and other types of male infertility.

\section{ACKNOWLEDGEMENTS}

The authors are indebted to all the patients for their cooperation. Also, the financial support of this study by Science and Research Branch, Fars University is acknowledged.

CONFLICT OF INTEREST. None declared.

\section{REFERENCES}

1. Krausz C, Forti G. Clinical aspects of male infertility. In: McElreavey K ed. Berlin: Springer-Verlage; 2000. pp. 1-21.
2. Comhaire FH. Towards More Objectivity in Diagnosis and Management of Male Infertility. Melbourne: Blackwell Scientific; 1987.

3. Egozcue S, Blanco J, Vendrell JM, Garcia F, Veiga A, Aran B, Barri PN, Vidal F, Egozcue J. Human male infertility: chromosome anomalies, meiotic disorders, abnormal spermatozoa and recurrent abortion. Human reproduction update 2000; 6(1): 93-105.

4. Jarow JP, Espeland MA, Lipshultz LI. Evaluation of the azoospermic patient. The journal of urology 1989; 142(1): 62-65.

5. Schlegel PN. Causes of azoospermia and their management. Reproduction, fertility, and development 2004; 16(5): 561-572.

6. Chillon M, Casals T, Mercier B, Bassas L, Lissens W, Silber S, Romey MC, Ruiz-Romero J, Verlingue C, Claustres M, Nunes V, Ferec C, Estivill X. Mutations in the cystic fibrosis gene in patients with congenital absence of the vas deferens. The new England journal of medicine 1995; 332(22): 1475-1480.

7. Anguiano A, Oates RD, Amos JA, Dean M, Gerrard B, Stewart C, Maher TA, White MB, Milunsky A. Congenital bilateral absence of the vas deferens. A primarily genital form of cystic fibrosis. JAMA 1992; 267(13): 1794-1797.

8. Hackstein JH, Hochstenbach R, Pearson PL. Towards an understanding of the genetics of human male infertility: lessons from flies. Trends in gnetics 2000; 16(12): 565572.

9. Cooke HJ, Saunders PT. Mouse models of male infertility. Nature reviews genetics 2002; 3(10): 790801

10. Matzuk MM, Lamb DJ. Genetic dissection of mammalian fertility pathways. Nature cell biology 2002; 4 Suppl: s41-s49.

11. Kerem B, Rommens JM, Buchanan JA, Markiewicz D, 
Cox TK, Chakravarti A, Buchwald M, Tsui LC. Identification of the cystic fibrosis gene: genetic analysis. Science 1989; 245(4922): 1073-1080.

12. Chu CS, Trapnell BC, Curristin S, Cutting GR, Crystal RG. Genetic basis of variable exon 9 skipping in cystic fibrosis transmembrane conductance regulator mRNA. Nature genetics 1993; 3(2): 151-156.

13. Phillipson GT, Petrucco OM, Matthews CD. Congenital bilateral absence of the vas deferens, cystic fibrosis mutation analysis and intracytoplasmic sperm injection. Human reproduction 2000; 15(2): 431-435.

14. Elborn JS. Cystic fibrosis. The lancet 2016; 388(10059): 2519-2531.

15. Dumur V, Gervais R, Rigot JM, Lafitte JJ, Manouvrier S, Biserte J, Mazeman E, Roussel P. Abnormal distribution of CF delta F508 allele in azoospermic men with congenital aplasia of epididymis and vas deferens. The lancet 1990; 336(8713): 512.

16. Claustres M. Molecular pathology of the CFTR locus in male infertility. Reproductive biomedicine online 2005; 10(1): 14-41.

17. Claustres M, Guittard C, Bozon D, Chevalier F, Verlingue C, Ferec C, Ferec C, Girodon E, Cazeneuve C, Bienvenu T, Lalau G, Dumur V, Feldmann D, Bieth E, Blayau M, Clavel C, Creveaux I, Malinge MC, Monnier N, Malzac P, Mittre H, Chomel JC, Bonnefont JP, Iron A, Chery M, Georges MD. Spectrum of CFTR mutations in cystic fibrosis and in congenital absence of the vas deferens in France. Human mutation 2000; 16(2): 143-156.

18. Gervais R, Dumur V, Rigot JM, Lafitte JJ, Roussel P, Claustres M, Demaille J. High frequency of the R117H cystic fibrosis mutation in patients with congenital absence of the vas deferens. The new England journal of medicine 1993 ; 328(6): 446-447.

19. Wang Z, Milunsky J, Yamin M, Maher T, Oates R, Milunsky A. Analysis by mass spectrometry of 100 cystic fibrosis gene mutations in 92 patients with congenital bilateral absence of the vas deferens. Human reproduction 2002; 17(8): 2066-2072.

20. Yu J, Chen Z, Ni Y, Li Z. CFTR mutations in men with congenital bilateral absence of the vas deferens (CBAVD): a systemic review and meta-analysis. Human reproduction 2012; 27(1): 25-35.

21. van der Ven K, Messer L, van der Ven H, Jeyendran RS, Ober C. Cystic fibrosis mutation screening in healthy men with reduced sperm quality. Human reproduction 1996; 11(3): 513-517.

22. Xu WM, Chen J, Chen H, Diao RY, Fok KL, Dong JD, Sun TT, Chen WY, Yu MK, Zhang XH, Tsang LL, Lau A, Shi QX, Shi QH, Huang PB, Chan HC. Defective CFTR-dependent CREB activation results in impaired spermatogenesis and azoospermia. PLoS one 2011; 6(5): e19120.

23. Xu WM, Chen J, Chen H, Diao RY, Fok KL, Da Dong J, Sun TT, Chen WY, Yu MK, Zhang XH, Tsang LL, Lau A, Shi QX, Shi QH, Huang PB, Chan HC. Defective CFTR-dependent CREB activation results in impaired spermatogenesis and azoospermia. PLoS one 2011; 6(5): e19120.
24. Ni WH, Jiang L, Fei QJ, Jin JY, Yang X, Huang XF. The CFTR polymorphisms poly-T, TG-repeats and M470V in Chinese males with congenital bilateral absence of the vas deferens. Asian journal of andrology 2012; 14(5): 687-690.

25. Organization WH. WHO Laboratory Manual for the Examination of Human Semen and Sperm-Cervical Mucus Interaction. $4^{\text {th }}$ ed. UK: Cambridge University Press; 1999.

26. Ferrie RM, Schwarz MJ, Robertson N, Vaudin S, Super M, Malone G, Little S. Development, multiplexing, and application of ARMS tests for common mutations in the CFTR gene. American journal of human genetics 1992; 51(2): 251-262.

27. Shrimpton AE. R117H and IVS8-5T cystic fibrosis mutation detection by restriction enzyme digestion. Molecular diagnosis 2000; 5(3): 235-238.

28. Castellani C, Cuppens H, Macek M Jr, Cassiman JJ, Kerem E, Durie P, Tullis E, Assael BM, Bombieri C, Brown A, Casals T, Claustres M, Cutting GR, Dequeker E, Dodge J, Doull I, Farrell P, Ferec C, Girodon E, Johannesson M, Kerem B, Knowles M, Munck A, Pignatti PF, Radojkovic D, Rizzotti P, Schwarz M, Stuhrmann M, Tzetis M, Zielenski J, Elborn JS. Consensus on the use and interpretation of cystic fibrosis mutation analysis in clinical practice. Journal of cystic fibrosis 2008; 7(3): 179-196.

29. Alibakhshi R, Kianishirazi R, Cassiman JJ, Zamani M, Cuppens H. Analysis of the CFTR gene in Iranian cystic fibrosis patients: identification of eight novel mutations. Journal of cystic fibrosis 2008; 7(2): 102-109.

30. Jalalirad M, Houshmand M, Mirfakhraie R, Goharbari M, Mirzajani F. First study of CF mutations in the CFTR gene of Iranian patients: detection of DeltaF508, G542X, W1282X, A120T, R117H, and R347H mutations. Journal of tropical pediatrics 2004; 50(6): 359-361.

31. Dayangac D, Erdem H, Yilmaz E, Sahin A, Sohn C, Ozguc M, Dork T. Mutations of the CFTR gene in Turkish patients with congenital bilateral absence of the vas deferens. Human reproduction 2004; 19(5): 10941100 .

32. Radpour R, Gilani MA, Gourabi H, Dizaj AV, Mollamohamadi S. Molecular analysis of the IVS8-T splice variant 5T and M470V exon 10 missense polymorphism in Iranian males with congenital bilateral absence of the vas deferens. Molecular human reproduction 2006; 12(7): 469-473.

33. Radpour R, Gourabi H, Gilani MA, Dizaj AV. Molecular study of (TG) $\mathrm{m}(\mathrm{T}) \mathrm{n}$ polymorphisms in Iranian males with congenital bilateral absence of the vas deferens. Journal of andrology 2007; 28(4): 541547.

34. Grangeia A, Carvalho F, Fernandes S, Silva J, Sousa M, Barros A. A novel missense mutation P1290S at exon20 of the CFTR gene in a Portuguese patient with congenital bilateral absence of the vas deferens. Fertility and sterility 2005; 83(2): 448-451.

35. Wu C, Hsieh-Li H, Lin YM, Chiang HS. Cystic fibrosis transmembrane conductance regulator gene screening 
and clinical correlation in Taiwanese males with congenital bilateral absence of the vas deferens. Human reproduction 2004; 19(2): 250-253.

36. Heidari S, Hojati Z, Motovali-Bashi M. Screening of two neighboring CFTR mutations in Iranian infertile men with non-obstructive azoospermia. International journal of fertility and sterility 2017; 10(4): 390-394.

37. Jiang L, Jin J, Wang S, Zhang F, Dai Y, Shi L, Zhang S. CFTR gene mutations and polymorphism are associated with non-obstructive azoospermia: From case-control study. Gene 2017; 626: 282-289.

38. Ślęzak R, Szczepaniak M, Pasińska M, Czemarmazowicz $\mathrm{H}$. The analysis of CFTR mutations in men with azoospermia, oligozoospermia and asthenozoospermia. Ginekologia polska 2007; 78(8): 605-610

39. Safinejad K, Darbouy M, Kalantar SM, Zeinali S, Mirfakhraie R, Yadegar L, Houshmand M. The prevalence of common CFTR mutations in Iranian infertile men with non-CAVD obstructive azoospermia by using ARMS PCR techniques. Journal of assisted reproduction and genetics 2011; 28(11): 1087-1090.

40. Stuppia L, Antonucci I, Binni F, Brandi A, Grifone N, Colosimo A, De Santo M, Gatta V, Gelli G, Guida V, Majore S, Calabrese G, Palka C, Ravani A, Rinaldi R, Tiboni GM, Ballone E, Venturoli A, Ferlini A, Torrente I, Grammatico P, Calzolari E, Dallapiccola B. Screening of mutations in the CFTR gene in 1195 couples entering assisted reproduction technique programs. European journal of human genetics 2005; 13(8): 959-964.

41. Sharma H, Mavuduru RS, Singh SK, Prasad R. Increased frequency of CFTR gene mutations identified in Indian infertile men with non-CBAVD obstructive azoospermia and spermatogenic failure. Gene 2014; 548(1): 43-47. 